\title{
Chemical Composition of Essential Oils Obtained from Heteromorpha arborescens (Spreng.) Cham. and Schltdl Leaves Using Two Extraction Methods
}

\author{
Taiwo Oluwafunmilola Abifarin (D), Gloria Aderonke Otunola (iD, \\ and Anthony Jide Afolayan $(\mathbb{D}$ \\ Medicinal Plants and Economic Development (MPED) Research Centre, Department of Botany, University of Fort Hare, \\ Alice 5700, South Africa \\ Correspondence should be addressed to Gloria Aderonke Otunola; gotunola@ufh.ac.za
}

Received 17 February 2020; Revised 30 October 2020; Accepted 21 November 2020; Published 3 December 2020

Academic Editor: Antonio M. Rabasco

Copyright (c) 2020 Taiwo Oluwafunmilola Abifarin et al. This is an open access article distributed under the Creative Commons Attribution License, which permits unrestricted use, distribution, and reproduction in any medium, provided the original work is properly cited.

\begin{abstract}
This study was aimed at comparing the essential oils obtained from Heteromorpha arborescens leaves by Solvent-Free Microwave Extraction (SFME) and Hydrodistillation (HD) methods in terms of their chemical compositions, yield, $\mathrm{CO}_{2}$ emission, and energy consumption. The solvent-free microwave extraction method indicated a higher oil yield of $0.7 \mathrm{~mL} / 200 \mathrm{~g}(0.35 \%)$ as compared to $0.59 \mathrm{~mL} / 200 \mathrm{~g}(0.295 \%)$ obtained through hydrodistillation. GC-MS analysis of the oils revealed a total of 52 chemical components from both methods with the presence of 35 (96.52\%) and 30 (71.15\%) chemical constituents for HD and SFME, respectively. The major constituents observed in the essential oil extracted by SFME methods include $\alpha$-pinene (6\%), D-limonene (11.27\%), $\beta$-ocimene (9.09\%), $\beta$-phellandrene (6.33\%), $\beta$-mycene (8.49\%), caryophyllene (5.96\%), and camphene (4.28\%). However, in the hydrodistillation method, the oil was majorly composed of $a$-pinene (4.41\%), $\beta$-pinene $(10.68 \%), \beta$-ocimene (6.30\%), germacrene$\mathrm{D}(5.09 \%)$, humulene (5.55\%), and $\alpha$-elemene (6.18\%). The SFME method was better in terms of saving energy (0.25 kWh against $4.2 \mathrm{kWh}$ of energy consumed), reduced $\mathrm{CO}_{2}$ emission ( $200 \mathrm{~g}$ against $3360 \mathrm{~g}$ of $\mathrm{CO}_{2}$ ), a higher yield, and better quality of essential oil due to the presence of higher valuable oxygenated compounds (8.52\%) against that of the hydrodistillation method (2.96\%). The SFME method is, therefore, a good alternative for extracting the oils of $H$. arborescens leaves since the essential oil yield is higher with more oxygenated compounds, considerable energy savings, lower cost, and reduced environmental burden at substantially reduced extraction time (30 min as opposed to $180 \mathrm{~min}$ ).
\end{abstract}

\section{Introduction}

Plants have a long history of therapeutic use in the management of diseases since time immemorial. Essential oils are natural, complex, and aromatic volatile compounds produced by plants, and they are generally present at low concentrations. These compounds possess antimicrobial and antioxidant activities, and they function in the treatment of various kinds of diseases [1]. They are also beneficial in various food industries (for preserving food against oxidation), as alternatives to artificial chemicals in cosmetics and perfumery industries for the production of various cologne waters, bathing lotions, hair lotions, and shampoos, and as components of disinfectants and insecticides [2].

Among aromatic plant species, the genus Heteromorpha (Apiaceae) consists of seven species which are restricted to temperate and subtropical Africa and Southern Yemen [3]. There is an increased interest for Apiaceae, especially in food science, because members of this family such as fennel, celery, dill, carrot, and caraway are commonly used. Apart from the biologically active essential oils found in this family, they contain coumarins, polyacetylenes, flavonoids, sesquiterpenes, and phthalides [4]. 
Heteromorpha arborescens (Spreng.) Cham. and Schltdl (Apiaceae) can be referred to as a large shrub, small or medium deciduous tree [5]. It is regarded as an important medicinal plant throughout its distribution area in tropical Africa and has been used for the treatment of many ailments including helminthiasis [6], abdominal pains, infertility, nervous disorders, and tuberculosis [5]. The plant is popularly known in parts of Africa for its therapeutic benefits and is therefore included in the monographic treatment of medicinal plants of South African medicine [7].

From previous studies, the volatile oil of $H$. arborescens leaves is known to contain sabinene, $\delta$-3-carene, myrcene, germacrene- $\mathrm{D}$, limonene, (Z)- $\beta$-ocimene, $\beta$-phellandrene, and $\alpha$-pinene as major constituents, and it possesses both antibacterial and antifungal activities [5]. Furthermore, the essential oil of $H$. arborescensis is vital in the development of new pharmaceutical and health products in Southern Africa for headache, inhalant, and aromatherapy [8].

Various conventional methods such as hydrodistillation, steam distillation, and cold pressing have been used for essential oil extraction in aromatic plants. However, the use of these methods has been disputable for successive determination of essential oil composition because the long extraction times at high temperatures may cause changes in the essential oil composition or degradation of unsaturated or esterified compounds and the loss of highly volatile compounds $[9,10]$. These limitations have led to the development of the solvent-free microwave extraction method in order to reduce the extraction time and obtain better quality of essential oils $[9,10]$.

The solvent-free microwave extraction (SFME) set up is referred to as a "green technology" which involves a combination of heat from the microwave and dry distillation at atmospheric pressure [11]. It is a sustainable extraction method which relies on reduced energy consumption, ensuring a safe and high quality end product [12]. It involves heating the fresh plant material in a microwave reactor, devoid of water or any solvent at all for $30 \mathrm{~min}$. The shortterm heating of the water in the plant material expands the plant cells causing the plant cells and oil producing glands to release the oil from the plant material [9]. SFME method has widely been employed in the extraction of oils from $\mathrm{Mel}$ alaica leucadendra L. [13], Ocimum basilicum L. [14], Kananga odorata [15], Pogostemon cabin [16], Cuminumcyminum L. and Zanthoxylum bungeanum Maxim [17], and many others. However, until now, there has been no studies on the comparison of the quality and yield of essential oils obtained from $H$. arborescens leaves using hydrodistillation and SFME methods. This work is therefore aimed at making a comparative study in terms of extraction yields and chemical compositions of essential oils obtained from $H$. arborescens leaves using hydrodistillation and solvent-free microwave extraction methods.

1.1. Plant Collection. Fresh leaves of $H$. arborescens were collected in June, 2019, on a site located on latitude $32^{\circ} 47^{\prime} 50.4^{\prime \prime} \mathrm{S}$ and $26^{\circ} 52^{\prime} 41.8^{\prime \prime} \mathrm{E}$ along Hogsback road, Alice Town, Eastern Cape, South Africa. The plant was authenticated by Prof. Cupido, a taxonomist in the Department of Botany, University of Fort Hare, and a voucher specimen (Abif2019/03) was deposited in the Giffen herbarium.

1.2. Chemicals. Distilled water and $\mathrm{n}$-hexane (chemical formular- $\mathrm{C}_{6} \mathrm{H}_{14}, \mathrm{MW}-86.18 \mathrm{~g} / \mathrm{mol}, \mathrm{BP}-68.73^{\circ} \mathrm{C}$, density$655 \mathrm{~kg} / \mathrm{m}^{3}$, and purity-95\%) used in the study were of analytical grade.

\section{Methodology}

2.1. Determination of Moisture Content. $200 \mathrm{~g}$ of the fresh $H$. arborescens leaves was weighed and recorded as $W_{f}$, dried at $80^{\circ} \mathrm{C}$ for 72 hours, and the dried leaves were then weighed and recorded as $\mathrm{W}_{\mathrm{d}}$. The moisture content of the leaves was calculated as

$$
\text { Moisture content }(\%)=\frac{W_{f} W_{d}}{W_{f}} \times 100 \text {. }
$$

2.2. Extraction by Hydrodistillation. $200 \mathrm{~g}$ of fresh $H$. arborescens leaves was subjected to hydrodistillation with a Clevenger-type apparatus as described by the European Pharmacopoeia and extracted with $1 \mathrm{~L}$ of water for $180 \mathrm{~min}$ at $100^{\circ} \mathrm{C}$. The essential oil was collected and analyzed by GCMS.

2.3. Solvent-Free Microwave Extraction (SFME). $200 \mathrm{~g}$ of fresh $H$. arborescens leaves was placed into the reactor without addition of any solvent. Microwave extraction was performed using a Milestone MAO20-A apparatus; a multimode microwave reactor $2.45 \mathrm{GHz}$ with a maximum delivered power of $500 \mathrm{~W}$ variable in $5 \mathrm{~W}$ increments. The essential oil was completely extracted at atmospheric pressure and $99.85^{\circ} \mathrm{C}(373 \mathrm{~K})$ within $30 \mathrm{~min}$; collected, and subjected to GC-MS analysis.

2.4. Energy Consumption and $\mathrm{CO}_{2}$ Emission. Power consumption was $500 \mathrm{~W}$ and $1400 \mathrm{~W}$ for SFME and hydrodistillation methods, respectively. The energy consumption and $\mathrm{CO}_{2}$ emission were calculated according to previous literature as energy consumption $(\mathrm{kWh})=\mathrm{Pt} / 1000$ and to obtain $1 \mathrm{kWh}$ from the combustion of coal or fossil fuel, and $800 \mathrm{~g}$ of $\mathrm{CO}_{2}$ will be emitted into the atmosphere [18-20].

2.5. Extraction Yields. The extraction yields of the essential oils obtained from both methods were calculated as

$$
\text { Extraction yield }(\%)=\frac{\text { Mass of extracted oil }}{\text { Mass of Fresh Leaves }} \times 100 \text {. }
$$

2.6. Gas Chromatography-Mass Spectroscopy Analysis. The essential oils extracted were separately analyzed by gas chromatography-mass spectroscopy (Agilent $6890 \mathrm{GC}$, coupled to an Agilent 5975 mass spectrometric detector). Gas 
TABLE 1: Chemical constituents of essential oils obtained from $H$. arborescens leaves by hydrodistillation and solvent-free microwave extraction methods.

\begin{tabular}{|c|c|c|c|c|c|c|}
\hline $\mathrm{S} / \mathrm{N}$ & Chemical compounds & Class of compounds & $\mathrm{KI}$ & RT & $\mathrm{HD}(\%)$ & SFME (\%) \\
\hline 1 & 3-Thujene & $\mathrm{MH}$ & 932 & 3.805 & 0.21 & - \\
\hline 2 & $\alpha$-Pinene & $\mathrm{MH}$ & 936 & 3.893 & 6.0 & 4.41 \\
\hline 3 & Camphene & $\mathrm{MH}$ & 948 & 4.028 & 4.28 & 0.58 \\
\hline 4 & 2-Thujene & $\mathrm{MH}$ & 952 & 4.195 & 2.33 & - \\
\hline 5 & $\beta$-Myrcene & $\mathrm{MH}$ & 983 & 4.293 & 8.49 & - \\
\hline 6 & $\alpha$-Phellandrene & $\mathrm{MH}$ & 998 & 4.463 & 6.33 & 1.78 \\
\hline 7 & 3-Carene & $\mathrm{MH}$ & 1002 & 4.509 & 1.88 & - \\
\hline 8 & D-limonene & $\mathrm{MH}$ & 1027 & 4.658 & 11.27 & - \\
\hline 9 & B-ocimene & $\mathrm{MH}$ & 1050 & 4.771 & 9.09 & 6.30 \\
\hline 10 & B-pinene & $\mathrm{MH}$ & 973 & 4.236 & - & 10.68 \\
\hline 11 & (-)-Myrtenal & $\mathrm{MH}$ & 1488 & 5.998 & 0.72 & - \\
\hline 12 & o-Cymene & $\mathrm{SH}$ & 1011 & 5.376 & - & 0.42 \\
\hline 13 & $\alpha$-Copaene & $\mathrm{SH}$ & 1390 & 7.314 & 3.30 & 2.30 \\
\hline 14 & $\beta$-cymene & $\mathrm{SH}$ & 1026 & 5.038 & 1.31 & 0.47 \\
\hline 16 & Caryophyllene & $\mathrm{SH}$ & 1419 & 7.644 & 5.96 & 3.64 \\
\hline 17 & $\beta$-Copaene & $\mathrm{SH}$ & 1102 & 7.691 & 2.77 & 0.44 \\
\hline 18 & $\beta$-Gurjurene & $\mathrm{SH}$ & 1089 & 7.393 & - & 1.42 \\
\hline 19 & $\Gamma$-Terpinene & $\mathrm{MH}$ & 987 & 4.896 & 1.30 & - \\
\hline 20 & (+)-4-Carene & $\mathrm{MH}$ & 998 & 5.127 & 3.80 & - \\
\hline 21 & Aromandendrene & $\mathrm{SH}$ & 1106 & 7.772 & 0.31 & 1.52 \\
\hline 22 & $\alpha$-Humulene & $\mathrm{SH}$ & 1446 & 7.869 & 5.55 & - \\
\hline 23 & $\gamma$-Muurolene & $\mathrm{SH}$ & 1442 & 7.967 & - & 2.38 \\
\hline 24 & D-germacrene & $\mathrm{SH}$ & 1481 & 8.035 & 8.92 & 5.09 \\
\hline 25 & $\gamma$-Elemene & $\mathrm{SH}$ & 1508 & 8.127 & - & 6.18 \\
\hline 26 & $\beta$-Cadinene & $\mathrm{SH}$ & 1126 & 8.246 & 2.24 & 3.98 \\
\hline 27 & $\alpha$-Calacorene & $\mathrm{SH}$ & 1133 & 8.406 & - & 1.12 \\
\hline 28 & (-)-Palustrol & $\mathrm{OM}$ & 1141 & 8.603 & - & 0.96 \\
\hline 30 & (-)4-Terpinol & $\mathrm{OM}$ & 1182 & 5.837 & 0.69 & - \\
\hline 31 & $\alpha$-Terpineol & $\mathrm{OM}$ & 1197 & 5.920 & 0.30 & - \\
\hline 32 & Spatulenol & OS & 1530 & 8.646 & - & 1.78 \\
\hline 33 & 3,4-Nonadiene & $\mathrm{MH}$ & 1048 & 6.143 & 0.16 & - \\
\hline 34 & Geraniol & $\mathrm{OM}$ & 1065 & 6.319 & 0.10 & - \\
\hline 35 & Caryophyllene oxide & OS & 1574 & 8.696 & - & 2.0 \\
\hline 36 & Ledol & $\mathrm{OM}$ & 1148 & 8.751 & - & 2.77 \\
\hline 37 & Ledene & $\mathrm{SH}$ & 1151 & 8.820 & - & 1.64 \\
\hline 38 & Isoledene & $\mathrm{SH}$ & 1375 & 7.795 & 0.93 & - \\
\hline 39 & $\beta$-Cubenene & $\mathrm{SH}$ & 1470 & 8.329 & 0.12 & - \\
\hline 40 & Nerodiol & OS & 1133 & 8.407 & 0.87 & - \\
\hline 41 & $\beta$-Selinene & $\mathrm{SH}$ & 1143 & 8.638 & 0.10 & - \\
\hline 43 & Napthalene & $\mathrm{SH}$ & 1155 & 8.917 & 0.34 & 0.74 \\
\hline 44 & $\alpha$-Cardinol & $\mathrm{OM}$ & 1161 & 9.063 & 0.24 & - \\
\hline 45 & 2-Isopropyl-5-methyl-9-methylene[4,4.0] dec-1-ene & $\mathrm{SH}$ & 1159 & 8.990 & 0.41 & - \\
\hline 46 & Phytol & OD & 1949 & 11.289 & 0.63 & - \\
\hline 47 & $\alpha$-Himachalene & $\mathrm{SH}$ & 1158 & 8.983 & - & 1.98 \\
\hline 48 & $\gamma$-Gurjunene & $\mathrm{SH}$ & 1163 & 9.092 & - & 1.57 \\
\hline 49 & Valencene & $\mathrm{SH}$ & 1410 & 2.09 & - & 2.09 \\
\hline 50 & $\alpha$-Bulnesene & $\mathrm{SH}$ & 1240 & 10.889 & - & 1.16 \\
\hline 51 & Kaur-16-ene & OD & 1214 & 10.994 & - & 0.91 \\
\hline \multirow[t]{4}{*}{52} & D-Citral & $\mathrm{OM}$ & 368 & 10.563 & - & 0.10 \\
\hline & Monoterpene hydrocarbons & & & & 57.17 & 23.75 \\
\hline & Sesquiterpenes & & & & 36.29 & 38.64 \\
\hline & Oxygenated compounds & & & & 2.96 & 8.52 \\
\hline
\end{tabular}

MH- monoterpenes hydrocarbons, SH- sesquiterpenes hydrocarbons, OD- oxygenated diterpenes, OM- oxygenated monoterpenes, OS- oxygenated sesquiterpenes, KI- Kovatz Index, RT- retention time.

chromatography-mass spectrometry was combined with a chromatography column HP-5.5\% phenylmethylsiloxane, with $30 \mathrm{~m}$ length, $0.32 \mathrm{~mm}$ film thickness, $0.25 \mu \mathrm{m}$ internal diameter. The injection port was held at $230^{\circ} \mathrm{C}$, while the interface was at $280^{\circ} \mathrm{C}$. The temperature was set from $50^{\circ} \mathrm{C}$ to $280^{\circ} \mathrm{C}$ at $10^{\circ} \mathrm{C}$ per minute, using helium as the carrier gas.

The chemical components of the essential oils were identified by comparing their mass spectra and retention 
indices with those in PubChem, NIST, and Wiley libraries [21]. The spectrogram of each identified compound was determined by integration of the peak areas.

\section{Results}

The moisture content of the $200 \mathrm{~g}$ of $H$. arborescens leaves was $10.20 \pm 0.95 \%$, and a slightly higher oil yield of $0.7 \mathrm{~mL} /$ $200 \mathrm{~g}(0.35 \%)$ was obtained through SFME after $30 \mathrm{~min}$ of extraction as compared to $0.59 \mathrm{~mL} / 200 \mathrm{~g}(0.295 \%)$ obtained after $180 \mathrm{~min}$ by the hydrodistillation method. The oils were pale-yellow liquids with fine aroma. For the energy consumption and environmental footprint, the amount of energy consumed and the quantity of carbon dioxide emitted into the atmosphere were higher for the hydrodistillation method (4.2 kWh and $3360 \mathrm{~g} \mathrm{CO}_{2} / \mathrm{g}$ of essential oil) as compared to the SFME method $\left(0.25 \mathrm{kWh}\right.$ and $200 \mathrm{~g} \mathrm{CO}_{2} / \mathrm{g}$ of essential oil).

A total of 52 compounds obtained by hydrodistillation and solvent-free microwave extraction methods are summarized in Table 1. Thirty-five compounds representing $96.52 \%$ of the total essential oil present were obtained in the hydrodistillation method. More specifically, the dominant compounds present in the hydrodistilled oil were D-limonene $(11.27 \%), \beta$-ocimene $(9.09 \%)$, D-germacrene $(8.92 \%)$, $\beta$-myrcene $(8.49 \%)$, and humulene $(5.55 \%)$. The SFME method, on the other hand, gave 30 compounds which accounted for $71.15 \%$ of the total oil, while $\beta$-pinene $(10.38 \%), \gamma$-elemene $(6.18 \%)$, and D-germacrene $(5.09 \%)$ were the major components. Thirteen (13) of the total components were common to oils extracted by both methods.

\section{Discussion}

Some conventional methods used for the extraction of essential oils are hydrodistillation, steam distillation, Microwave-Assisted Extraction (MAE), and solvent extraction. Although these techniques have been used over time, they have some limitations such as longer time of extraction, low extraction effectiveness, reduced oil quality due to degradation of unsaturated or ester compounds through thermal or hydrolytic effects, and negative impacts on the environment [22]. SFME and Microwave Hydrodiffusion and Gravity (MHG) methods are two new green techniques employed in the extraction of quality essential oils at a lower cost, reduced time, and environmental footprints [23].

The chemical compositions of the essential oil of $H$. arborescens leaves obtained by the solvent-free microwave extraction method have been compared with those which were obtained by the hydrodistillation method. Our study indicates that the essential oil yield obtained by the SFME method was slightly higher with shorter extraction time $(0.35 \%$ for $30 \mathrm{~min})$ when compared with that by the hydrodistillation method $(0.295 \%$ for $180 \mathrm{~min})$. The lower yield obtained by the hydrodistillation method may be attributed to increasing extraction time [24]. The present study also revealed that the SFME method reduced energy consumption and $\mathrm{CO}_{2}$ emission by about 16 times. Similar observations were made in previous studies $[25,26]$.

The two oils were characterized with monoterpene hydrocarbons, sesquiterpenes, and oxygenated compounds. However, monoterpenes and sesquiterpenes were dominant in the SFME and hydrodistilled oils, respectively, but higher quantity of oxygenated compounds was present in the SFME-extracted oil. This is in agreement with the essential oil compositions of Angelica sylvestris L. var. sylvestris fruits [27], Ferula glauca, Ferula arrigonii, and Ferula communis [28], all members of the Apiaceae family. Lower quantity of monoterpenes with higher sesquiterpenes and oxygenated compounds was observed in the SFME-derived oil. Monoterpene hydrocarbons are less important than oxygenated compounds in terms of their impact on the pleasant aroma of essential oils, while the oxygenated compounds are highly fragrant and, hence, the most important [26]. Nevertheless, monoterpenes are generally useful for therapeutic purposes as antibacterial and antifungal agents [29]. Sesquiterpenes also possess anti-inflammatory and anticarcinogenic properties [1].

Higher oxygenated compounds observed in the solventfree microwave-extracted oil indicate the superiority of the method over hydrodistillation and could be attributed to reduced water content in the system which would have minimized the thermal and hydrolytic degradation of oxygenated compounds when compared with the hydrodistillation method [30, 31].

The major constituents observed in the essential oil extracted by the SFME method include $a$-pinene $(6 \%)$, D-limonene (11.27\%), $\beta$-ocimene $(9.09 \%), \beta$-phellandrene (6.33\%), $\beta$-mycene $(8.49 \%)$, caryophyllene $(5.96 \%)$, and camphene $(4.28 \%)$. However, in the hydrodistillation method, the oil was majorly composed of $\alpha$-pinene $(4.41 \%)$, $\beta$-pinene $(10.68 \%), \quad \beta$-ocimene $(6.30 \%)$, germacrene-D (5.09\%), humulene (5.55\%), and $a$-elemene (6.18\%). This is in correlation with the findings of Mwangi et al. [32] and Chagonda et al. [33] in their observations that sabinene, $\delta$-3carene, myrcene, germacrene-D, limonene, $(\mathrm{Z})-\beta$-ocimene, $\beta$-phellandrene, and $\alpha$-pinene are major constituents in $H$. arborescens leaves. The absence of sabinene and $\delta$-3carene in this study could be as a result of the difference in their geographic areas or some biotic and biotic factors in the environment [34]. It is interesting to note that 22 compounds were unique to only the hydrodistillation method and 17 were distinctive to the SFME methods, while 13 were common to both methods. This buttresses the point that the chemical composition of essential oils is dependent on the extraction methods [35].

\section{Conclusions}

This study has shown that the chemical composition of the essential oils obtained from H.arborescens leaves is dependent on the extraction method. The SFME method resulted in a higher yield in terms of quantity and an essential oil of better quality due to the presence of higher valuable oxygenated compounds than that which was obtained by hydrodistillation. Furthermore, the use of the SFME method 
indicated lower energy consumption and $\mathrm{CO}_{2}$ emission. It can therefore be concluded that the SFME method is considered as a good alternative for the extraction of essential oil from $H$. arborescens leaves at shorter extraction time, reduced energy consumption, lower cost, and environmental footprint when compared with the hydrodistillation method.

\section{Data Availability}

All underlying data supporting the results can be found in the manuscript.

\section{Ethical Approval}

Ethical approval was granted by the University of Fort Hare Animal and Plant Use Research Ethics Committee, South Africa, with protocol number AFO111SABI01.

\section{Conflicts of Interest}

The authors declare that they do not have any conflicts of interest regarding the publication of this paper.

\section{Authors' Contributions}

GAO and T.O.A designed the experiments, T.O.A performed the experiments, analyzed data, and wrote the draft. GAO and AJA coordinated and revised the manuscript. TOA, GAO, and AJA read and approved the final manuscript.

\section{Acknowledgments}

This research was financially supported by Govan Mbeki Research and Development Center, University of Fort Hare (C127).

\section{References}

[1] I. O. Lawal, H. Ajay, P. Dairo, and P. O. Ogunbamowo, "Comparative studies of essential oils of Clausena anisata (Hook) using solvent-free microwave extraction and hydrodistillation methods," Journal of Medicinal Plants for Economic Development, vol. 3, no. 1, 2019.

[2] M. Chenni, D. El Abed, N. Rakotomanomana, X. Fernandez, and F. Chemat, "Comparative study of essential oils extracted from Egyptian basil leaves (Ocimum basilicum L.) using hydro-distillation and solvent-free microwave extraction," Molecules, vol. 21, no. 1, p. 113, 2016.

[3] P. J. D. Winter and B.-E. V. Wyk, "A revision of the genus Heteromorpha (Apiaceae)," Kew Bulletin, vol. 51, no. 2, pp. 225-265, 1996.

[4] L. P. Christensen and K. Brandt, "Bioactive polyacetylenes in food plants of the Apiaceae family: occurrence, bioactivity and analysis," Journal of Pharmaceutical and Biomedical Analysis, vol. 41, no. 3, pp. 683-693, 2006.

[5] A. Maroyi, "Heteromorpha arborescens: a review of its Botany, medicinal uses, and pharmacological properties," Asian Journal of Pharmaceutical and Clinical Research, vol. 11, no. 11, pp. 75-82, 2018.

[6] M. Adamu, V. P. Bagla, and J. N. Eloff, "Fractionation of Heteromorpha arborescens var abyssinica (Apiaceae) leaf extracts based on polarity leads to a marked change in cytotoxicity that may yield a commercially useful product," South African Journal of Botany, vol. 103, pp. 36-40, 2016.

[7] B. E. Van Wyk, B. Van Oudtshoorn, and N. Gericke, Medicinal Plants of South Africa, Briza Publications, Pretoria, South Africa, 2013.

[8] B.-E. Van Wyk, "The potential of South African plants in the development of new medicinal products," South African Journal of Botany, vol. 77, no. 4, pp. 812-829, 2011.

[9] H. Kusuma, D. Putri, D. Putri, I. Dewi, and M. Mahfud, "Solvent-free microwave extraction as the useful tool for extraction of edible essential oils," Chemistry \& Chemical Technology, vol. 10, no. 2, pp. 213-218, 2016.

[10] M. Moradalizadeh, N. Samadi, and P. Rajaei, "Comparison of hydrodistillation, microwave hydrodistillation and solventfree microwave methods in analysis of the essential oils from aerial parts of Haplophyllum robustum Bge. by GC/MS method," International Journal of Advanced Biological and Biomedical Research, vol. 1, no. 9, pp. 1058-1067, 2013.

[11] A. Farhat, C. Ginies, M. Romdhane, and F. Chemat, "Ecofriendly and cleaner process for isolation of essential oil using microwave energy," Journal of Chromatography A, vol. 1216, no. 26, pp. 5077-5085, 2009.

[12] F. Chemat, M. A. Vian, and G. Cravotto, "Green extraction of natural products: concept and principles," International Journal of Molecular Sciences, vol. 13, no. 7, pp. 8615-8627, 2012.

[13] A. W. Ismanto, H. S. Kusuma, and M. Mahfud, "Solvent-free microwave extraction of essential oil from Melaleuca leucadendra L.” EDP Sciences, vol. 156, 2018.

[14] H. S. Kusuma, D. K. Y. Putri, D. Kharisma et al., "Solvent-free microwave extraction of essential oil from dried basil (Ocimum basilicum L.) leaves," Chemistry \& Chemical Technology, vol. 12, no. 4, pp. 543-548, 2018.

[15] M. Ekawati, D. K. Y. Putri, I. E. P. Dewi, and H. S. Kusuma, "Extraction of essential oil from cananga (cananga odorata) using solvent-free microwave extraction: a preliminary study," Rasayan Journal of Chemistry, vol. 10, no. 1, pp. 86-91, 2017.

[16] H. S. Kusuma, A. Altway, and M. Mahfud, "Solvent-free microwave extraction of essential oil from dried patchouli (Pogostemon cablin Benth) leaves," Journal of Industrial and Engineering Chemistry, vol. 58, pp. 343-348, 2018.

[17] Y. Wang, J. You, Y. Yu et al., "Analysis of ginsenosides in Panax ginseng in high pressure microwave-assisted extraction," Food Chemistry, vol. 110, no. 1, pp. 161-167, 2008.

[18] H. S. Kusuma, D. K. Y. Putri, I. Triesty, and M. Mahfud, "Comparison of microwave hydrodistillation and solvent-free microwave extraction for extraction of agarwood oil," Chiang Mai Journal Of Science, vol. 46, no. 4, pp. 741-755, 2019.

[19] M. A. Ferhat, B. Y. Meklati, J. Smadja, and F. Chemat, "An improved microwave Clevenger apparatus for distillation of essential oils from orange peel," Journal ofChromatography A, vol. 1112, no. 1-2, pp. 121-126, 2006.

[20] C. Bernard, S. Chaussedent, A. Monteil et al., "Application of molecular dynamics techniques and luminescent probes to the study of glass structure: the $\mathrm{SiO} 2-\mathrm{GeO} 2$ case," Journal of Noncrystalline Solids", vol. 284, no. 1-3, pp. 68-72, 2001.

[21] B. Omoruyi, A. Afolayan, and G. Bradley, "Chemical composition profiling and antifungal activity of the essential oil and plant extracts of Mesembryanthemum edule (L.) bolus leaves," African Journal of Traditional, Complementary and Alternative Medicines, vol. 11, no. 4, pp. 19-30, 2014.

[22] M. Bouazaoui, C. Kinowski, and S. Turrell, "Application of molecular dynamics techniques and luminescent probes to 
the study of glass structure: the $\mathrm{SiO} 2-\mathrm{GeO} 2$ case," Journal of Non-crystalline Solids, vol. 284, no. 1-3, pp. 68-72, 2001.

[23] H. H. Rassem, A. H. Nour, and R. M. Yunus, "Techniques for extraction of essential oils from plants: a review," Australian Journal of Basic and Applied Sciences, vol. 10, no. 16, pp. pp117-127, 2016.

[24] Z. Wang, L. Ding, T. Li et al., "Improved solvent-free microwave extraction of essential oil from dried Cuminum cyminum L. and Zanthoxylum bungeanum Maxim," Journal of Chromatography A, vol. 1102, no. 1-2, pp. 11-17, 2006.

[25] D. K. Y. Putri, H. S. Kusuma, M. E. Syahputra, D. Parasandi, and M. Mahfud, "The extraction of essential oil from patchouli leaves (Pogostemon cablin Benth) using microwave hydrodistillation and solvent-free microwave extraction methods," in IOP Conference Series: Earth and Environmental ScienceVol. 101, IOP Publishing, Bristol, UK, 2017.

[26] M. E. Lucchesi, F. Chemat, and J. Smadja, "Solvent-free microwave extraction of essential oil from aromatic herbs: comparison with conventional hydro-distillation," Journal of Chromatography, vol. 1043, no. 2, pp. 323-327, 2004.

[27] T. Özek, G. Özek, K. H. C. Başer, A. Duran, and M. Sagiroglu, "Composition of the essential oils of Angelica sylvestris L. var. sylvestris isolated from the fruits by different isolation techniques," Journal of Essential Oil Research, vol. 20, no. 5, pp. 408-411, 2008.

[28] A. Sahebkar and M. Iranshahi, "Volatile constituents of the genus Ferula (Apiaceae): a review," Journal of Essential Oil Bearing Plants, vol. 14, no. 5, pp. 504-531, 2011.

[29] A. Marchese, C. Arciola, R. Barbieri et al., "Update on monoterpenes as antimicrobial agents: a particular focus on p-cymene," Materials, vol. 10, no. 8, p. 947, 2017.

[30] M. E. Lucchesi, J. Smadja, S. Bradshaw, W. Louw, and F. Chemat, "Solvent free microwave extraction of Elletaria cardamomum L.: a multivariate study of a new technique for the extraction of essential oil," Journal of Food Engineering, vol. 79, no. 3, pp. 1079-1086, 2007.

[31] M. Bendahou, A. Muselli, M. Grignon-Dubois et al., "Antimicrobial activity and chemical composition of Origanum glandulosum Desf. essential oil and extract obtained by microwaveextraction: comparison with hydrodistillation," Food Chemistry, vol. 1, no. 106, pp. 132-139, 2008.

[32] J. W. Mwangi, K. J. Achola, W. Lwande, A. Hassanali, and R. Laurent, "Volatile components ofheteromorpha trifoliata (wendl.) eckl. \& zey," Flavour and Fragrance Journal, vol. 9, no. 5, pp. 241-243, 1994.

[33] L. S. Chagonda, C. D. Makanda, and J.-C. Chalchat, "The essential oils ofOcimum canum Sims (basilic camphor) andOcimum urticifolia Roth from Zimbabwe," Flavour and Fragrance Journal, vol. 15, no. 1, pp. 23-26, 2000.

[34] K. Hosni, A. Kerkenni, W. Medfei, N. Ben Brahim, and H. Sebei, "Volatile oil constituents of Rosa canina L.: quality as affected by the distillation method," Organic Chemistry International, vol. 2010, Article ID 621967, 7 pages, 2010.

[35] E. Ghasemi, F. Raofie, and N. M. Najafi, "Application of response surface methodology and central composite design for the optimisation of supercritical fluid extraction of essential oils from Myrtus communis L. leaves," Food Chemistry, vol. 126, no. 3, pp. 1449-1453, 2011. 